Article

\title{
Pseudoalteromone B: A Novel 15C Compound from a Marine Bacterium Pseudoalteromonas sp. CGH2XX
}

\section{Yu-Hsin Chen 1,2,3, Jimmy Kuo ${ }^{2,3}$, Jui-Hsin Su ${ }^{2,3}$, Tsong-Long Hwang ${ }^{4}$, Yung-Husan Chen ${ }^{3}$,} Chia-Hung Lee ${ }^{1,2}$, Ching-Feng Weng ${ }^{1,2, *}$ and Ping-Jyun Sung ${ }^{1,2,3,5, *}$

1 Department of Life Science and Institute of Biotechnology, National Dong Hwa University, Hualien 974, Taiwan; E-Mails: kb5634@yahoo.com.tw (Y.-H.C.); chlee016@mail.ndhu.edu.tw (C.-H.L.)

2 Graduate Institute of Marine Biotechnology, National Dong Hwa University, Pingtung 944, Taiwan; E-Mails: jimmy@nmmba.gov.tw (J.K.); x2219@nmmba.gov.tw (J.-H.S.)

3 National Museum of Marine Biology and Aquarium, Pingtung 944, Taiwan; E-Mail: tony_chen72001@yahoo.com.tw

4 Graduate Institute of Natural Products, Chang Gung University, Taoyuan 333, Taiwan; E-Mail: ht1@mail.cgu.edu.tw

5 Department of Marine Biotechnology and Resources and Division of Marine Biotechnology, Asia-Pacific Ocean Research Center, National Sun Yat-sen University, Kaohsiung 804, Taiwan

* Authors to whom correspondence should be addressed;

E-Mails: cfweng@mail.ndhu.edu.tw (C.-F.W.); pjsung@nmmba.gov.tw (P.-J.S.);

Tel.: +886-3-863-3637 (C.-F.W.); Fax: +886-3-863-3630 (C.-F.W.);

Tel.: +886-8-882-5037 (P.-J.S.); Fax: +886-8-882-5087 (P.-J.S.).

Received: 12 June 2012; in revised form: 12 July 2012 / Accepted: 12 July 2012 /

Published: 20 July 2012

Abstract: A novel 15C compound, pseudoalteromone B (1), possessing a novel carbon skeleton, was obtained from a marine bacterium Pseudoalteromonas sp. CGH2XX. This bacterium was originally isolated from a cultured-type octocoral Lobophytum crassum, that was growing in cultivating tanks equipped with a flow-through sea water system. The structure of 1 was established by spectroscopic methods. Pseudoalteromone B (1) displayed a modestly inhibitory effect on the release of elastase by human neutrophils.

Keywords: pseudoalteromone; Pseudoalteromonas; anti-inflammatory; Lobophytum crassum; elastase 


\section{Introduction}

Marine bacteria belonging to the genus Pseudoalteromonas sp. (family Pseudoalteromonadaceae) have proven to be not only an important source of various antibiotics, but have also played an interesting role in marine ecology [1-4]. In the continuing research aimed at the discovery of new natural substances from marine microorganisms, an organic extract of the bacterium identified as Pseudoalteromonas sp. CGH2XX, which was originally isolated from a cultured-type octocoral Lobophytum crassum (family Alcyonacea), exhibited significant cytotoxicity toward the HL-60 (human acute promyelocytic leukemia) and CCRF-CEM (human T cell acute lymphoblastic leukemia) tumor cells $\left(\mathrm{IC}_{50}=0.9,1.2 \mu \mathrm{g} / \mathrm{mL}\right.$ ) and displayed a significant inhibitory effect (inhibition rate $45.1 \%$ ) on the release of elastase by human neutrophils at a concentration of $10 \mu \mathrm{g} / \mathrm{mL}$. We isolated a novel $15 \mathrm{C}$ compound, pseudoalteromone B (1) (Figure 1), from this microorganism. The structure of 1 was established by spectroscopic methods and this compound displayed a modestly inhibitory effect on the release of elastase by human neutrophils.

Figure 1. The structure of pseudoalteromone B (1).

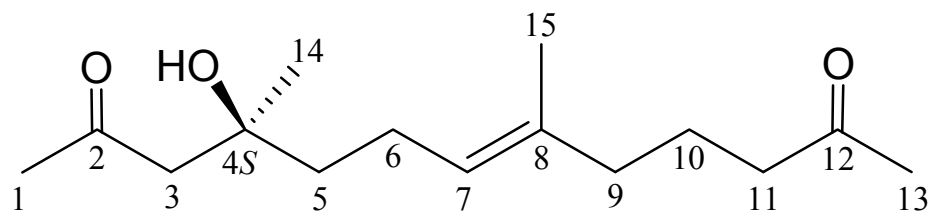

\section{Results and Discussion}

Pseudoalteromone B (1) was isolated as an oil and had the molecular formula $\mathrm{C}_{15} \mathrm{H}_{26} \mathrm{O}_{3}$, as determined by HRESIMS $\left(\mathrm{C}_{15} \mathrm{H}_{26} \mathrm{O}_{3}+\mathrm{Na}, \mathrm{m} / z\right.$ found 277.1779 , calculated 277.1780$)$ indicating three degrees of unsaturation. The IR absorption bands at 3502 and $1706 \mathrm{~cm}^{-1}$ were characteristic for the hydroxy and ketone groups.

Table 1. ${ }^{1} \mathrm{H}\left(400 \mathrm{MHz}, \mathrm{CDCl}_{3}\right)$ and ${ }^{13} \mathrm{C}\left(100 \mathrm{MHz}, \mathrm{CDCl}_{3}\right) \mathrm{NMR}$ data for $\mathbf{1}$.

\begin{tabular}{cll}
\hline Position & \multicolumn{1}{c}{$\boldsymbol{\delta}_{\mathbf{H}}(\boldsymbol{J}$ in Hz) } & \multicolumn{1}{c}{$\boldsymbol{\delta}_{\mathbf{C}}, \mathbf{M u l t}_{\mathbf{l}}$} \\
\hline 1 & $2.18 \mathrm{~s}$ & $31.9, \mathrm{CH}_{3}$ \\
2 & & $211.0, \mathrm{qC}$ \\
$3 \mathrm{a} / \mathrm{b}$ & $2.58 \mathrm{~d}(17.2) ; 2.65 \mathrm{~d}(17.2)$ & $52.3, \mathrm{CH}_{2}$ \\
4 & & $71.5, \mathrm{qC}$ \\
5 & $1.51 \mathrm{~m}$ & $41.9, \mathrm{CH}_{2}$ \\
6 & $2.04 \mathrm{~m}$ & $22.5, \mathrm{CH}_{2}$ \\
7 & $5.09 \mathrm{tq}(7.2,1.2)$ & $124.8, \mathrm{CH}$ \\
8 & & $134.6, \mathrm{qC}$ \\
9 & $1.96 \mathrm{t}(7.2)$ & $38.8, \mathrm{CH}_{2}$ \\
10 & $1.66 \mathrm{quintet}(7.2)$ & $21.8, \mathrm{CH}_{2}$ \\
11 & $2.37 \mathrm{t}(7.2)$ & $43.0, \mathrm{CH}_{2}$ \\
12 & & $209.1, \mathrm{qC}$ \\
13 & $2.12 \mathrm{~s}$ & $29.9, \mathrm{CH}_{3}$ \\
14 & $1.22 \mathrm{~s}$ & $26.7, \mathrm{CH}_{3}$ \\
15 & $1.58 \mathrm{br} \mathrm{s}$ & $15.7, \mathrm{CH}_{3}$ \\
\hline
\end{tabular}


The ${ }^{1} \mathrm{H}$ and ${ }^{13} \mathrm{C}$ NMR data of $\mathbf{1}$ (Table 1) showed the presence of 15 carbon signals, which were identified by the assistance of a DEPT spectrum as four methyls, six $\mathrm{sp}^{3}$ methylenes, an $\mathrm{sp}^{2}$ methine, an $\mathrm{sp}^{3}$ quaternary carbon, and three $\mathrm{sp}^{2}$ quaternary carbons including two ketone carbonyls. The ${ }^{1} \mathrm{H}$ NMR spectrum of 1 showed a signal of olefinic proton $\left(\delta_{\mathrm{H}} 5.09,1 \mathrm{H}, \mathrm{tq}, J=7.2,1.2 \mathrm{~Hz}, \mathrm{H}-7\right)$, two acetyl methyls $\left(\delta_{\mathrm{H}} 2.18,3 \mathrm{H}, \mathrm{s}, \mathrm{H}_{3}-1 ; 2.12,3 \mathrm{H}, \mathrm{s}, \mathrm{H}_{3}-13\right)$, a vinyl methyl $\left(\delta_{\mathrm{H}} 1.58,3 \mathrm{H}\right.$, br s, $\left.\mathrm{H}_{3}-15\right)$, a tertiary methyl attaching at an oxygenated quaternary carbon $\left(\delta_{\mathrm{H}} 1.22,3 \mathrm{H}, \mathrm{s}, \mathrm{H}_{3}-14\right)$ and six pairs of methylene protons $\left(\delta_{\mathrm{H}} 2.65,1 \mathrm{H}, \mathrm{d}, J=17.2 \mathrm{~Hz} ; 2.58,1 \mathrm{H}, \mathrm{d}, J=17.2 \mathrm{~Hz}, \mathrm{H}_{2}-3 ; 2.37,2 \mathrm{H}, \mathrm{t}, J=7.2 \mathrm{~Hz}, \mathrm{H}_{2}-11 ; 2.04\right.$, $2 \mathrm{H}, \mathrm{m}, \mathrm{H}_{2}-6 ; 1.96,2 \mathrm{H}, \mathrm{t}, J=7.2 \mathrm{~Hz}, \mathrm{H}_{2}-9 ; 1.66,2 \mathrm{H}$, quintet, $J=7.2 \mathrm{~Hz}, \mathrm{H}_{2}-10 ; 1.51,2 \mathrm{H}, \mathrm{m}, \mathrm{H}_{2}-5$ ).

The constitution of the carbon skeleton of 1 was elucidated initially by the ${ }^{1} \mathrm{H}-{ }^{1} \mathrm{H}$ COSY and HMBC correlations of 1 (Figure 2), it was possible to establish the separate spin systems that map out the proton sequences from $\mathrm{H}_{2}-5 / \mathrm{H}_{2}-6 / \mathrm{H}-7$ and $\mathrm{H}_{2}-9 / \mathrm{H}_{2}-10 / \mathrm{H}_{2}-11$. These data, together with the HMBC correlations between $\mathrm{H}_{3}-1 / \mathrm{C}-2$, C-3; $\mathrm{H}_{2}-3 / \mathrm{C}-2$, C-4, C-5; H $2-5 / \mathrm{C}-4$, C-6; H-7/C-9; $\mathrm{H}_{2}-9 / \mathrm{C}-7$, C-8, C-10, C-11; $\mathrm{H}_{2}-10 / \mathrm{C}-8$, C-9, C-11, C-12; $\mathrm{H}_{2}-11 / \mathrm{C}-9$, C-10, C-12; and $\mathrm{H}_{3}-13 / \mathrm{C}-11$, C-12, permitted elucidation of the main straight carbon skeleton. The vinyl methyl at $\mathrm{C}-8$ was confirmed by the HMBC correlations between $\mathrm{H}-7, \mathrm{H}_{2}-9 / \mathrm{C}-15$; and $\mathrm{H}_{3}-15 / \mathrm{C}-7, \mathrm{C}-8$, C-9; and further supported by an allylic coupling between $\mathrm{H}-7$ and $\mathrm{H}_{3}-15(J=1.2 \mathrm{~Hz})$. Based on these data, together with the HMBC correlations between $\mathrm{H}_{3}-14 / \mathrm{C}-3, \mathrm{C}-4, \mathrm{C}-5$ and $\mathrm{H}_{2}-3, \mathrm{H}_{2}-5 / \mathrm{C}-14$, the planar structure of 1 was established.

Figure 2. The ${ }^{1} \mathrm{H}-{ }^{1} \mathrm{H}$ COSY and selective HMBC correlations (protons $\rightarrow$ quaternary carbons) of $\mathbf{1}$.

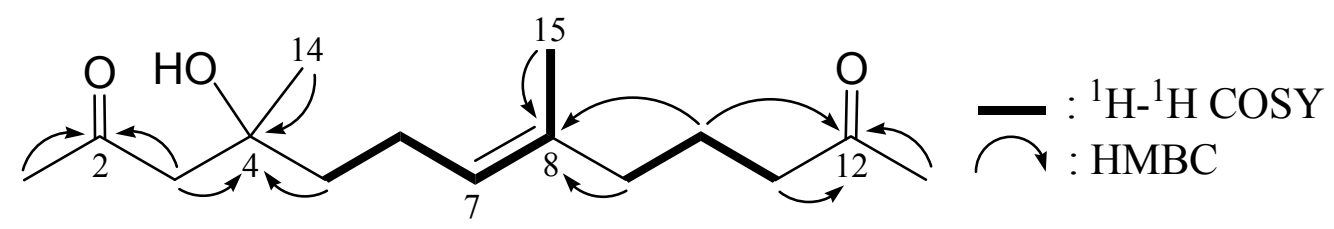

In the NOESY experiment of $\mathbf{1}$, a correlation between $\mathrm{H}-7$ with $\mathrm{H}_{2}-9$, as well as the lack of correlation between $\mathrm{H}-7$ and $\mathrm{H}_{3}-15$, reflected the E-configuration of C-7/8 double bond. Furthermore, by comparison of the rotation value of $1\left([\alpha]_{\mathrm{D}}^{23}-20\left(c 0.03, \mathrm{CHCl}_{3}\right)\right)$ with that of a known synthetic compound, (S)-4-hydroxy-4-methyl-6-phenylhexan-2-one (2) $\left([\alpha]_{\mathrm{D}}^{25}-14.5\left(c 1.1, \mathrm{CHCl}_{3}\right)\right.$ ) (Figure 3) [5], the absolute configuration for the C-4 chiral center of $\mathbf{1}$ was determined as $S$ form as that of $\mathbf{2}$. Based on the above findings, the structure of $\mathbf{1}$ was determined unambiguously.

Figure 3. The structure of (S)-4-hydroxy-4-methyl-6-phenylhexan-2-one (2).

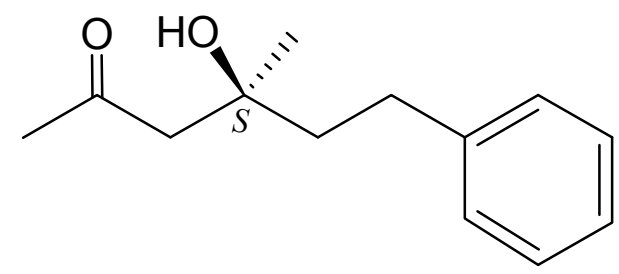

The in vitro cytotoxicity of pseudoalteromone B (1) toward HCT116 (human colorectal carcinoma), K-562 (human chronic myelogenous leukemia), HL-60 (human acute promyelocytic leukemia), CCRF-CEM (human T cell acute lymphoblastic leukemia), T-47D (human breast ductal carcinoma), and MDA-MB-231 (human breast adenocarcinoma) cells was tested. Unfortunately, the new compound 1 
described herein is not active toward the above cells (all $\mathrm{IC}_{50}$ values $>20 \mu \mathrm{g} / \mathrm{mL}$ ). The in vitro anti-inflammatory effect of $\mathbf{1}$ was tested. Pseudoalteromone B (1) displayed a modestly inhibitory effect (inhibition rate $20.7 \%$ ) on the release of elastase by human neutrophils at a concentration of $10 \mu \mathrm{g} / \mathrm{mL}$.

\section{Experimental Section}

\subsection{General Experimental Procedures}

Optical rotations were measured on a Jasco P-1020 polarimeter. IR spectra were recorded on a Jasco FT/IR-4100 infrared spectrophotometer. The NMR spectra were recorded on a Varian Mercury Plus 400 FT-NMR at $400 \mathrm{MHz}$ for ${ }^{1} \mathrm{H}$ and $100 \mathrm{MHz}$ for ${ }^{13} \mathrm{C}$, in $\mathrm{CDCl}_{3}$, respectively. Proton chemical shifts were referenced to the residual $\mathrm{CHCl}_{3}$ signal $\left(\delta_{\mathrm{H}} 7.26 \mathrm{ppm}\right) .{ }^{13} \mathrm{C}$ NMR spectra were referenced to the center peak of $\mathrm{CDCl}_{3}$ at $\delta_{\mathrm{C}} 77.1 \mathrm{ppm}$. ESIMS and HRESIMS data were recorded on a Bruker APEX II mass spectrometer. Silica gel (Merck, 230-400 mesh) and Sephadex LH-20 (Amersham Biosciences) were used for column chromatography. TLC was carried out on precoated Kieselgel $60 \mathrm{~F}_{254}(0.25 \mathrm{~mm}$, Merck); spots were visualized by spraying with $10 \% \mathrm{H}_{2} \mathrm{SO}_{4}$ solution followed by heating.

\subsection{Marine Bacteria Isolation, Culture Conditions and Extract Preparation}

A marine bacterium number CGH2XX was isolated from soft coral Lobophytum crassum that was growing in cultivating tanks equipped with a flow-through sea water system [4]. The bacterium strain CGH2XX was 98.3\% identical with Pseudoalteromonas sp. H02P24-23 (Genebank accession no. HQ161380) on the basis of $16 \mathrm{~S}$ rDNA gene sequence. The marine bacterium was cultured in $2.5 \mathrm{~L}$ flasks containing $1 \mathrm{~L} \mathrm{M} 1$ broth (not containing agar) with $80 \%$ seawater. Flasks were incubated at $25{ }^{\circ} \mathrm{C}$ on a rotatory shaker at $120 \mathrm{rpm}$. After five days of incubation, extraction of the culture broth $(10.0 \mathrm{~L})$ with ethyl acetate $($ EtOAc, $2 \times 10.0 \mathrm{~L})$ yielded $1.71 \mathrm{~g}$ of crude extract. The extracts obtained were stored at $-20{ }^{\circ} \mathrm{C}$.

\subsection{Separation}

Crude extract was separated on Sephadex LH-20 and eluted using a mixture of dichloromethane and methanol $(1: 1)$ to yield 17 fractions. Fraction 6 was selected for further study and purified by silica gel, using a mixture of $n$-hexane and EtOAc (2:1) as a mobile phase to afford compound 1 (4.2 mg).

Pseudoalteromone B (1): colorless oil; $[\alpha]_{\mathrm{D}}^{23}-20\left(c 0.03, \mathrm{CHCl}_{3}\right)$; IR (neat) $v_{\max } 3502,1706 \mathrm{~cm}^{-1}$; ${ }^{1} \mathrm{H}\left(\mathrm{CDCl}_{3}, 400 \mathrm{MHz}\right)$ and ${ }^{13} \mathrm{C}\left(\mathrm{CDCl}_{3}, 100 \mathrm{MHz}\right) \mathrm{NMR}$ data, see Table 1; ESIMS: $\mathrm{m} / z 277(\mathrm{M}+\mathrm{Na})^{+}$; HRESIMS: $m / z 277.1779$ (calcd for $\mathrm{C}_{15} \mathrm{H}_{26} \mathrm{O}_{3}+\mathrm{Na}, 277.1780$ ).

\subsection{Cytotoxicity Testing}

The cytotoxicity of compound $\mathbf{1}$ was assayed with a modification of the MTT [3-(4,5-dimethyl thiazol-2-yl)-2,5-diphenyltetrazolium bromide] colorimetric method. Cytotoxicity assays were carried out according to previously described procedures [6-8]. 


\subsection{Elastase Release by Human Neutrophils}

Human neutrophils were obtained by means of dextran sedimentation and Ficoll centrifugation. Elastase release experiments were performed using MeO-Suc-Ala-Ala-Pro-Valp-nitroanilide as the elastase substrate [9-11].

\section{Conclusions}

In a previous study [4], an ubiquinone derivative, pseudoalteromone A, was isolated from Pseudoalteromonas sp. CGH2XX, and this compound was found to be cytotoxic toward MOLT-4 (human acute lymphoblastic leukemia) and T-47D (human breast ductal carcinoma) cells $\left(\mathrm{IC}_{50}=3.8,4.0 \mu \mathrm{g} / \mathrm{mL}\right)$ and displayed moderately inhibitory effects on the generation of superoxide anion and the release of elastase (inhibition rates 38.0,20.2\%) by human neutrophils at a concentration of $10 \mu \mathrm{g} / \mathrm{mL}$ [12]. However, as described in the beginning of this communication, the organic extract of Pseudoalteromonas sp. CGH2XX showed significant cytotoxicity and anti-inflammatory activity. At this stage, the results showed that pseudoalteromone B (1) displayed a modestly anti-inflammatory activity and this compound was not cytotoxic toward HCT116, K-562, HL-60, CCRF-CEM, T-47D and MDA-MB-231 cells. We suggested that the other active components exist in the other fractions. The possible activity for pseudoalteromone B (1) will be studied if we can get enough material from Pseudoalteromonas sp. CGH2XX. Furthermore, to the best of our knowledge, compounds pseudoalteromones A and B, were the first two compounds from the marine bacterium belonging to the genus Pseudoalteromonas associated with octocorals.

\section{Acknowledgments}

This work was supported by grants from the National Dong Hwa University; the National Museum of Marine Biology and Aquarium (Grant No. 10120022); the Division of Marine Biotechnology, Asia-Pacific Ocean Research Center, National Sun Yat-sen University (Grant No. 00C-0302-05); and the National Science Council (Grant No. NSC 101-2325-B-291-001, 101-2320-B-291-001-MY3 and 98-2320-B-291-001-MY3), Taiwan, awarded to P.-J.S.

\section{References and Notes}

1. Bowman, J.P. Bioactive compound synthetic capacity and ecological significance of marine bacterial genus Pseudoalteromonas. Mar. Drugs 2007, 5, 220-241.

2. Fehér, D.; Barlow, R.S.; Lorenzo, P.S.; Hemscheidt, T.K. A 2-substituted prodiginine, 2-(p-hydroxybenzyl)prodigiosin, from Pseudoalteromonas rubra. J. Nat. Prod. 2008, 71, 1970-1972.

3. Fehér, D.; Barlow, R.; McAtee, J.; Hemscheidt, T.K. Highly brominated antimicrobial metabolites from a marine Pseudoalteromonas sp. J. Nat. Prod. 2010, 73, 1963-1966.

4. Chen, Y.-H.; Lu, M.-C.; Chang, Y.-C.; Hwang, T.-L.; Wang, W.-H.; Weng, C.-F.; Kuo, J.; Sung, P.-J. Pseudoalteromone A: a novel bioactive ubiquinone from a marine bacterium Pseudoalteromonas sp. CGH2XX (Pseudoalteromonadaceae). Tetrahedron Lett. 2012, 53, 1675-1677.

5. Chen, I.-H.; Kanai, M.; Shibasaki, M. Copper(I) - Secondary diamine complex-catalyzed enantioselective conjugate boration of linear $\beta, \beta$-disubstituted enones. Org. Lett. 2010, 12, 4098-4101. 
6. Doxorubicin was used as a reference compound in cytototxicity testing. Doxorubicin showed cytotoxicity toward HCT116, K-562, HL-60, CCRF-CEM, T-47D, and MDA-MB-231 cells $\left(\mathrm{IC}_{50}=1.8,0.8,0.2,0.1,1.5\right.$ and $\left.1.7 \mu \mathrm{g} / \mathrm{mL}\right)$.

7. Alley, M.C.; Scudiero, D.A.; Monks, A.; Hursey, M.L.; Czerwinski, M.J.; Fine, D.L.; Abbott, B.J.; Mayo, J.G.; Shoemaker, R.H.; Boyd, M.R. Feasibility of drug screening with panels of human tumor cell lines using a microculture tetrazolium assay. Cancer Res. 1988, 48, 589-601.

8. Scudiero, D.A.; Shoemaker, R.H.; Paull, K.D.; Monks, A.; Tierney, S.; Nofziger, T.H.; Currens, M.J.; Seniff, D.; Boyd, M.R. Evaluation of a soluble tetrazolium/formazan assay for cell growth and drug sensitivity in culture using human and other tumor cell lines. Cancer Res. 1988, 48, 4827-4833.

9. In the in vitro anti-inflammatory bioassay, the inhibitory effect on the release of elastase by activated neutrophils was used as an indicator. For significant activity of pure compounds, an inhibition rate $\geq 40 \%$ is required (inhibition rate $\leq 10 \%$, not active; $20 \% \geq$ inhibition rate $\geq 10 \%$, weakly anti-inflammatory; $40 \% \geq$ inhibition rate $\geq 20 \%$, modestly anti-inflammatory). Elastatinal was used as a reference compound in anti-inflammatory activity test $\left(\mathrm{IC}_{50}=31.9 \mu \mathrm{g} / \mathrm{mL}\right)$.

10. Hwang, T.-L.; Wang, C.-C.; Kuo, Y.-H.; Huang, H.-C.; Wu, Y.-C.; Kuo, L.-M.; Wu, Y.-H. The hederagenin saponin SMG-1 is a natural FMLP receptor inhibitor that suppresses human neutrophil activation. Biochem. Pharmacol. 2010, 80, 1190-1200.

11. Yu, H.-P.; Hsieh, P.-W.; Chang, Y.-J.; Chung, P.-J.; Kuo, L.-M.; Hwang, T.-L. 2-(2-Fluorobenz-amido)benzoate ethyl ester (EFB-1) inhibits superoxide production by human neutrophils and attenuates hemorrhagic shock-induced organ dysfunction in rats. Free Radic. Biol. Med. 2011, 50, 1737-1748.

12. The authors regret that there is an error in pages 1 and 2 of [4] (pages 1675 and 1676 of the issue). In [4], the ubiquinone, pseudoalteromone A, was reported to display an inhibitory effect on the release of elastase (inhibition rate $45.1 \%$ ) by human nuetrophils at a concentration of $10 \mu \mathrm{g} / \mathrm{mL}$. However, after detailed collating, we found this data was cited incorrectly. The data (inhibition rate $45.1 \%$ ) expressed an inhibitory effect of an organic extract from the marine bacterium Pseudoalteromonas sp. CGH2XX on the release of elastase by human nuetrophils as presented in this study. The in vitro anti-inflammatory effects of pseudoalteromone A were tested again. Pseudoalteromone A displayed moderately inhibitory effects on the generation of superoxide anion and the release of elastase (inhibition rates $38.0 \%$ and $20.2 \%$ ) by human neutrophils at a concentration of $10 \mu \mathrm{g} / \mathrm{mL}$. Diphenyl indonium (DPI) and elastatinal were used as reference compounds in anti-inflammatory activity testing. DPI displayed an inhibitory effect on superoxide anion generation $\left(\mathrm{IC}_{50}=0.9 \mu \mathrm{g} / \mathrm{mL}\right)$, and elastatinal exhibited an inhibitory effect on elastase release $\left(\mathrm{IC}_{50}=31.9 \mu \mathrm{g} / \mathrm{mL}\right)$ by human neutrophils, respectively. The authors apologize for any inconvenience caused by this error.

Samples Availability: Not available.

(C) 2012 by the authors; licensee MDPI, Basel, Switzerland. This article is an open access article distributed under the terms and conditions of the Creative Commons Attribution license (http://creativecommons.org/licenses/by/3.0/). 